\title{
Innovation of Learning to Write Poetry through Time- Lapse Video Media
}

\author{
Triana Ulfah ${ }^{1}$, Andayani $^{2}$ and Sumarwati ${ }^{3}$ \\ \{trianaulfah@student.uns.ac.id ${ }^{1}$, andayani@staff.uns.ac.id ${ }^{2}$, \& sumarwati@staff.uns.ac.id ${ }^{3}$ \} \\ ${ }^{1,2,3}$ Universitas Sebelas Maret, Surakarta, Indonesia
}

\begin{abstract}
Time-lapsed videos can optimize learning in Indonesian, especially in basic competencies to write poetry. The purpose of this research is to describe the innovation in learning to write poetry through time-lapse video media. Timelapse videos are applied at State Senior High School 1 Bae in Kudus Regency. This research used descriptive qualitative method. Sources of data in this research are in the form of supporting documents and interviews of teachers and students. Data collection techniques used interviews, observation, and document analysis. The results of this study indicated that: (1) time-lapse videos can make positive contributions that are fun, attractive to students and have a positive impact on increasing student learning outcomes, and (2) the use of time-lapse videos gets $92 \%$ positive response from teachers and students, so that it can be said that the use of time-lapse video as an effective learning media to be applied in the learning process.
\end{abstract}

Keywords: learning media, videos, time-lapse, writing, poetry

\section{INTRODUCTION}

Indonesian language learning consists of four aspects of language skills that must be mastered, namely listening, speaking, reading and writing. These four skills are basically a unity that cannot be separated from one aspect with another[1]. The writing process requires high-level thinking so that it produces a series of words that have a specific purpose. Writing is an act of exploring the mind that aims to create ideas that can be used as material for stringing words so that the writing has a relationship or interaction with the reader[2].

Writing activities are used as a medium to express themselves based on their experience of knowledge. One of them is the ability to write poetry. Writing poetry can be used as a means to determine students 'creativity in expressing ideas and testing students' knowledge in literary learning[3]. For students, they can use this facility to express themselves and train sensitivity to mastery of the diction they have. Poetry can provide many opportunities for students to enrich vocabulary[4].

The reality of a unique phenomenon occurs in education in Indonesia. It has become commonplace in this country that Indonesian students' learning achievement in various evaluations takes the form of tests, often lower than foreign language subjects[5]. Not only in 
daily tests, this phenomenon occurs both at the National Examination (UN). In the end, Indonesian is considered a language that is difficult to learn. Especially in learning to write poetry, students have difficulty in expressing ideas, and feelings into writing. Because of these constraints, this research offers a way to overcome them by using learning media. The use of instructional media with video models can generally help students[6]. Students more easily understand learning material because learning innovations are able to provide stimulus to students. Learning innovation using media will make students happy and easier to understand material[7]. One of the media offered is a time-lapse video. The object taken can be the phenomenon of sunrise, movement of plants, clouds and still other phenomena.

\section{METHOD}

This research uses descriptive qualitative method with the main focus to describe innovation in learning to write poetry through time-lapse video media. This research was conducted at State Senior High School 1 Bae in Kudus district on learning to write poetry. Data sources are Indonesian language teachers and 32 students of ten ${ }^{\text {th }}$ grade students of Social 1. The population in this research was ten ${ }^{\text {th }}$ grade students of Social 1 at State Senior High School 1 Bae. Samples in this study took 2 results of writing poetry from 32 students based on time-lapse video media. The sampling technique used cluster random sampling, which is random sampling without regard to the level in the population. Data collection techniques used was interviews and observations. The interview and observation techniques were conducted to obtain information about the teacher's perception of learning to write poetry and time-lapse video media. The interview technique was carried out to students to get information about students' perceptions of time-lapse video media. Document analysis techniques are conducted to collect student writing data. The technique used was purposive sampling, namely the selection of data tailored to the needs of the research.

\section{RESULT AND DISCUSSION}

Poetry writing activity is self-expression through thoughts and feelings in written form with aspects of language or choices of words that can be understood and meaning conveyed to the reader[8]. This research used poetry material from Basic Competence of 4.17 to write poetry by paying attention to the builder element. The results of interviews with students show that writing poetry is one of the difficult lessons. Students have difficulty in expressing ideas, giving rise to imagination and difficulty in choosing words. Interviews were conducted on Indonesian language teachers who showed that writing skills had their own challenges in each student paradigm. Students have difficulty in expressing ideas in written language. Writing skills are complex activities in text-based learning[9].

Poetry writing activities have more difficulties than other writing activities because students must be able to imagine ideas into writing[10]. Good teaching and learning activities are able to get the focus of students in participating in teaching and learning. Based on observations, researcher found several problems faced by teachers, namely students not interested and lack of interest in participating in teaching and learning activities. This happened because of the lack of creativity of the teacher in choosing learning strategies. Students feel bored with teaching and learning activities because of the lack of teacher innovation in material delivery[11]. The teacher used lecturing method and being guided by Student Workbooks[12]. Thelack of interest, attention, and involvement of students in the leaning process affecting students learning outcomes that are not maximal[13]. Previous research has several problems including; (1) lack of student interest in writing poetry; (2) the 
limited vocabulary possessed by students can inhibit expressing ideas; (3) lack of teacher creativity in delivering material; (4) teachers still use conventional methods[14]. Students have difficulty in writing good poetry. Students tend to compile poetry in the form of narration or description, because mastery of diction is still low[15]. Thus, there is a solution to the use of a media that supports to produce new ideas that can be used as material for writing. The use of media will trigger sensory experiences and produce ideas that are naturally acquired[16].

\subsection{Time-Lapse Video as a Learning Media}

Learning process is a system that consists of several components that are interconnected and affect the components of one another. Learning has several components including: (1) goals; (2) teaching materials; (3) learning methods; (4) learning media; (5) evaluation; (6) students; (7) teacher; (8) facilities and infrastructure. If one component in learning is not used or its use is not optimal, then in the process of achieving learning objectives that are less than optimal. For example, teacher cannot choose, provide, expose the media well, it can cause problems that will make students unable to receive information or material properly. These problems will have an impact on learning outcomes and student learning interest decreases. Thus, the use of good learning media will support student learning outcomes and be able to achieve learning goals.

Using the right media is the key to be success in the learning process. Selection of media is by considering several components, such as the quality of information, delivery of information, and student interest in the media[17]. Media is used as an educational tool that can help teachers deliver information or material to students effectively and efficiently in achieving learning goals. The use of media can make learning fun so students actively follow because students understand better than not using media[18].

Learning media in in 4.0 eras are growing rapidly and increasingly varied. Teachers are increasingly faced with technological sophistication, so that teachers are forced to follow their development. One of the learning media is video media. Video is a collection of several images taken using a digital tool[19]. Video is a type of audio visual media. It is learning media that can be seen and heard. Video media has several advantages including: (1) videos add a new dimension to learning. Video presents moving and audible images; (2) videos can display a phenomenon and event that can be seen in an easy way and not necessarily to the scene[20]. Video is able to invite someone to feel like that. Therefore, students will feel with the five sensory experiences while studying, so the learning process will be accepted and understood by students.

The researcher applied a time-lapse video as a medium for learning to write poetry. Timelapse video media testing was conducted at Senior High School 1 Bae to obtain data on student perceptions of the media. Based on the interview shows the percentage of students' perceptions of time-lapse video media as follows.

Table 1. Students' perceptions of time-lapse video media

\begin{tabular}{|l|c|}
\hline \multicolumn{1}{|c|}{ Statement } & Percentage (\%) \\
\hline $\begin{array}{l}\text { I am creative in writing poetry after seeing video } \\
\text { media -time-lapse }\end{array}$ & $92 \%$ \\
\hline $\begin{array}{l}\text { I was not motivated to write poetry after seeing } \\
\text { video media -time-lapse }\end{array}$ & $8 \%$ \\
\hline
\end{tabular}

The percentage obtained from students' perceptions of time-lapse video media in the statement "I am creative in writing poetry after seeing time-lapse video media" has a high percentage 
value of $92 \%$ of the percentage in the statement "I am not motivated to write poetry after seeing the media video-time-lapse "which only gets $8 \%$ of students' perceptions of time-lapse video media. The percentage data can be concluded that the use of time-lapse video media can optimize the teaching and learning process in poetry material.

\subsection{Innovation in Learning to Write Poetry Through Time-Lapse Video Media}

The ability to write poetry requires supporting facilities, so that it can support the work of students. Some of the results of previous studies stated that video as a learning media that has a positive contribution to student learning outcomes. Time-lapse film media that is applied to learning, students is more easily observe objects directly and require a short time[21]. The use of video time-lapse media can improve poetry writing skills. Basic considerations in research to train students to think logically, concretely, and students focus on learning media. Then the learning process becomes more active, creative, and memorable.

The researcher conducted a document analysis from the students' writing results. The researcher took samples randomly from the results of writing poetry in ten ${ }^{\text {th }}$ grade students of Social 1 . Student poetry was analyzed based on structural poetry consisting of seven aspects. The researcher takes one aspect of assessment, namely the majas used in writing poetry. Samples were taken randomly and analyzed based on the study used as follows.

Table 2. Sample Poetry Writing Documents

\begin{tabular}{|c|c|}
\hline Sample 1 & Sample 2 \\
\hline $\begin{array}{l}\text { Pantai Bandengan } \\
\text { Memandangmu adalah sebuah anugrah } \\
\text { Serasa menenangkan hati ini } \\
\text { Melihat persembahan tari ombak } \\
\text { Terasa hati kian menangis haru } \\
\quad \text { Matahari bahagia tersenyum menyinari } \\
\text { Pohon melambai bagai memanggil } \\
\text { Angin berbisik tenangkan hati } \\
\text { Pasir putih menambah indahmu }\end{array}$ & $\begin{array}{l}\text { Pantai } \\
\text { Sang surya tersenyum cerah } \\
\text { Menampakkan kemilau yang indah } \\
\text { Ku biarkan angin menerpa wajah } \\
\text { Membuat perasaan kian membuncah } \\
\text { Kurasakan ketenangan } \\
\text { Terputar semua kenangan } \\
\text { Kubiarkan tumbuh menari } \\
\text { Dibawah hangatnya mentari } \\
\text { Deruan ombak iringi melodi }\end{array}$ \\
\hline $\begin{array}{l}\text { Bandengan Beach } \\
\text { Looking at you is a gift } \\
\text { This heart feels calm } \\
\text { See the wave dance } \\
\text { Feeling more hearty crying } \\
\text { The sun happily smiled } \\
\text { The waving tree is calling } \\
\text { The wind whispers calm the heart } \\
\text { White sand adds to your beauty }\end{array}$ & $\begin{array}{l}\text { Beach } \\
\text { The sun smiled brightly } \\
\text { Show beautiful sheen } \\
\text { I let the wind hit his face } \\
\text { Makes feeling more bloated } \\
\text { I feel calm } \\
\text { Rotating all memories } \\
\text { I let it grow to dance } \\
\text { Under the warm sun } \\
\text { The roar of the waves accompanied the } \\
\text { melody }\end{array}$ \\
\hline
\end{tabular}

The first sample "Bandengan Beach"is a personification cycle that can be proven from the quotation of the poem "Seeing the wave dance offerings," "The sun happily smiled", "The tree waving is calling", "The wind whispers calm the heart". The hyperbole progression in the first stanza quote of the 4th line "Feeling more hearty crying". The second sample titled "Beach" created imagination by using personification in the quote "The sun smiled brightly", "All the memories I rotated let me grow dancing", "The roar of the waves accompanied the melody". Based on the analysis the achievement of student learning outcomes is very visible with the 
presence of time-lapse video media. The poem excerpt shows that the first sample and the second sample can think creatively and create imaginations that will be used as material for writing after viewing time-lapse video media.

Innovation in learning to write poetry through time-lapse video media gets a positive response from students. Students' perceptions of time-lapse video media show that $92 \%$ like learning that implements time-lapse video media. The percentage results were evidenced by the perceptions of $10^{\text {th }}$ grade students of Social 1 in State Senior High School 1 Bae. They claimed that the use of time-lapse video media was able to improve students' creativity and interest in participating in the learning process [22].

Students are able to find ideas and imagination that will be used as material for writing poetry. The implementation of time-lapse video media has a positive impact on learning to write poetry including: (1) time-lapse video media can provide stimulus so as to increase student interest; (2) students are happy and interested because the use of time-lapse video learning media is rarely applied to Indonesian language learning; (3) students are able to create ideas and imagination that will be used as material for writing poetry; (4) Thus, time-lapse videos have good feasibility based on student and teacher responses.

\section{CONCLUSION}

Innovation of learning through time-lapse video media can increase students' interest in following the learning process. Students are able to find ideas and imagination that will be used as material for writing poetry. Time-lapse videos can make positive contributions that are fun, attractive to students and have a positive impact on increasing student learning outcomes. The use of time-lapse videos gets $92 \%$ positive response from teachers and students, it can be said that time-lapse videos as learning media are feasible to be applied in the learning process of writing poetry. Some of the advantages that have been described prove that learning innovation through time-lapse video provides benefits to the world of education as a learning media especially in learning to write poetry with the provision of video selection in accordance with learning objectives, learning materials, and facilities and infrastructure.

\section{REFERENCE}

[1] K. Saddhono, Pembelajaran Keterampilan Berbahasa Indonesia. Yogyakarta: Graha Ilmu, 2014.

[2] J. D. Williams, Preparing to Teach Writing: Research, Theory, and Practice. London: Routledge, 2014.

[3] S. İ. Kuru Gönen, "Implementing Poetry in the Language Class: A Poetry-Teaching Framework for Prospective English Language Teachers," Adv. Lang. Lit. Stud., vol. 9, no. 5 , p. $28,2018$.

[4] A. L. Freyn and D. Ed, "Effects of a Multimodal Approach on ESL / EFL University Students 'Attitudes towards Poetry," vol. 8, no. 8, pp. 80-83, 2017.

[5] Andayani, Problema dan Aksioma: dalam Metodologi Pembelajaran Bahasa Indonesia. Yogyakarta: Deepublish, 2015.

[6] K. Saddhono and D. Sulaksono, "Indoglish as adaptation of english to Indonesian: Change of society in big cities of Indonesia," IOP Conf. Ser. Earth Environ. Sci., vol. 126, no. $1,2018$.

[7] W. Setyawan, A. Anindyarini, D. Suhita, F. Aziz, and E. Kustriyono, "Optimization of Piwulang Text Learning by Using Media of Powerquiz Game," vol. 7, pp. 302-305, 2018. 
[8] K. Saddhono, "Integrating culture in Indonesian language learning for foreign speakers at Indonesian universities," J. Lang. Lit., vol. 6, no. 2, pp. 273-276, 2015.

[9] K. Saddhono et al., "Effective sentence assignment as the key to improve skill of writing exposition with online learning media Quipper," Int. J. Eng. Technol., vol. 7, no. 2.13 Special Issue 13, pp. 437-441, 2018.

[10] J. Widodo, S. Suwandi, and S. S. Tarjana, "Peningkatan Kemampuan Menulis Puisi Melalui Penerapan Strategi Identifikasi Berbasisi Kecerdasan Majemuk pada Siswa Kelas X-A SMA Negeri 1 Gemolong Tahun Ajaran 2011/2012," J. Pendidik. Bhs. dan Sastra ISSN 1693-623X Vol 1, No 1, 2013 (hal 37-53) http//jurnal.pasca.uns.ac.id, vol. 1, no. 1, pp. 37-53, 2013.

[11] A. D. Ekasari, A. Nuryatin, and W. Suwito, "Peningkatan Keterampilan Menulis Puisi Melalui Strategi Pikir Plus dengan Menggunakan Media Gambar Peristiwa," Seloka J. Pendidik. Bhs. dan Sastra Indones., vol. 3, no. 1, pp. 1-7, 2014.

[12] M. Amin, "Development of Video Compact Disc as Learning Media to Improve Exposition Writing Ability," Proc. Int. Conf. Sci. Technol. Internet Things, 2019.

[13] S. Asiah and H. Anwar, "The Effect of the Using of ICT-Based Media and Learning Interest to the Students' Learning Results," Proc. Int. Conf. Sci. Technol. Internet Things, 2019.

[14] S. W. Anggraeni, "Penggunaan Media Lagu Anak Dalam Meningkatkan Hasil Pembelajaran Menulis Puisi," vol. 1, no. 1, pp. 49-60, 2016.

[15] F. Liao, "The relationship between L2 students 'writing experiences and their perceived poetry writing ability," Stud. Second Lang. Learn. Teach., vol. 7, no. 4, pp. 619-647, 2017.

[16] L. S. Rebecca, "Writing Poems from Idea Bundles," J. Learn. through Arts, vol. 13, no. $1,2017$.

[17] M. Kobayashi, "Students 'Media Preferences in Online Learning," Turkish Online J. Distance Educ., vol. 18, no. 3, pp. 4-15, 2017.

[18] S. Chotimah, M. Bernard, and S. M. Wulandari, "Contextual approach using VBA learning media to improve students ' mathematical displacement and disposition ability," J. Phys. Conf. Ser., vol. 948, no. 1, p. 12025, 2018.

[19] F. Camastra and A. Vinciarelli, Machine Learning for Audio, Image and Video Analysis: Theory and Applications. London: Spinger, 2015.

[20] Daryanto, Media Pembelajaran. Bandung: Satu Nusa, 2015.

[21] M. Harrison-pitaniello, "Using Students-Produced Time-Lapse Plant Movie to Communicate Concepts in Plants Biology," J. Microbiol. Biol. Educ. JMBE, vol. 14, no. 1, pp. 101-102, 2013.

[22] K. Saddhono and M. Rohmadi, "A Sociolinguistics Study on the Use of the Javanese Language in the Learning Process in Primary Schools in Surakarta, Central Java, Indonesia." Int. Edu. Stu., vol. 7 no.6 pp 25-30, 2014 